\title{
Frantz's tumor in a female patient with diarrhea: case report of a rare pancreatic neoplasm
}

\author{
Tumor de Frantz em paciente do sexo feminino com diarreia: relato de caso de \\ neoplasia pancreática rara
}

\author{
Luís Arthur Brasil Gadelha Farias, Danielle Souza Carvalho Maciel², \\ Mariana Silton Pinheiro de Araujo ${ }^{3}$, Angélica Maria Holanda Pascoal da Silva ${ }^{4}$, \\ Rebeca Viana Brígido de Moura Cairutas ${ }^{4}$, Débora Praciano Correia Férrer Leite ${ }^{4}$, \\ Gardênia Costa do Carmo ${ }^{4}$, Francisco Sérgio Rangel de Paula Pessoa ${ }^{4}$
}

Farias LABG, Maciel DSC, Araujo MSP, Silva AMHP, Cairutas RVBM, Leite DPCF, Carmo GC, Pessoa FSRP. Frantz's tumor in a female patient with diarrhea: case report of a rare pancreatic neoplasm / Tumor de Frantz em paciente do sexo feminino com diarreia: relato de caso de neoplasia pancreática rara. Rev Med (São Paulo). 2018 March-Apr.;97(2):248-51.

RESUMO: O tumor pseudopapilar sólido, também conhecido como tumor de Frantz, é um tumor raro do pâncreas. Relatamos o caso de uma paciente de 25 anos com dor abdominal, febre, diarréia e perda de peso.TC de abdome com contraste revelou pâncreas alargado com lesão hipodensa de aparência nodular e calcificações periféricas. Foi decidido realizar pancreatectomia subtotal com linfadenectomia e optou-se pela esplenectomia com biópsia hepática intra-operatória. $\mathrm{O}$ anatomopatológico da ressecção cirúrgica do tumor pancreático revelou tumor pseudopapilar sólido compatível com o tumor de Frantz. A imuno-histoquímica confirmou os achados histopatológicos. Ela evoluiu com fístula pancreática e pancreatite resolvida após 15 dias. Atualmente, está sendo acompanhada ambulatorialmente em nosso serviço com remissão completa dos sintomas.

Descritores: Neoplasias pancreáticas/terapia; Dor abdominal; Diarréia; Perda de peso.
ABSTRACT: Solid pseudopapillary tumor, also known as frantz tumor, is a rare tumor of the pancreas. We report a case of 25 -yearold female patient with abdominal pain, fever, diarrhea and weight loss. Contrast abdominal CT showed enlarged pancreas with a hypodense lesion of nodular appearance and peripheral calcifications.It was decided to perform subtotal pancreatectomy with lymphadenectomy, and opted for splenectomy and intraoperative liver biopsy. The pathology of surgical resection of the pancreatic tumor showed solid pseudopapillary tumor compatible with Frantz's tumor. Immunohistochemistry confirmed histopathological findings. She evolved with pancreatic fistula and pancreatitis resolved after 15 days. Currently, it is being followed up in our service with complete remission of symptoms.

Keywords: Pancreatic neoplasms/therapy; Abdominal pain; Diarrhea; Weight loss.

1. Faculdade de Medicina, Universidade Federal do Ceará (UFC), Fortaleza, Ceará, Brasil. https://orcid.org/0000-0002-8978-9903.

2. Faculdade de Medicina, Universidade Estadual do Ceará (UECE), Fortaleza, Ceará, Brasil. https://orcid.org/0000-0002-5341-8481.

3. Faculdade de Medicina, Centro Universitário Unichristus (Unichristus), Fortaleza, Ceará, Brasil. https://orcid.org/0000-0003-3945-1776.

4. Serviço de Gastroenterologia, Hospital Geral de Fortaleza (HGF), Fortaleza, Ceará, Brasil. ORCID: Silva AMHP - https://orcid. org/0000-0002-6128-7493; Cairutas RVBM - https://orcid.org/0000-0002-3943-3984; Leite DPCF - https://orcid.org/0000-0001-62424317; Carmo GC - https://orcid.org/0000-0003-4491-865X; Pessoa FSRP - https://orcid.org/0000-0001-6025-5601.

Corresponding author: Luis Arthur Brasil Gadelha Farias. Department of Community Health, School of Medicine, Federal University of Ceará. Rua Prof. Costa Mendes, 1608, $5^{\circ}$ andar, Rodolfo Teófilo. Fortaleza, Ceará, Brazil. CEP: 60430-140. Email: luisarthurbrasilk@ hotmail.com. 


\section{INTRODUCTION}

$\mathrm{T}$ he Frantz's tumor, also known as solid pseudopappillary tumor of the pancreas, was first described by Virginia Kneeland Frantz in $1959^{1}$. It comprises approximately 0.2 to $2.7 \%$ of all tumors of the pancreas. It is found in the majority of cases in young women between 18 and 35 years of age and is considered a neoplasia with a small degree of malignancy, since it is capable of complete surgical resection, which is possible in most cases. The most common manifestation is a slowly growing mass with or without pain and metastases are uncommon ${ }^{2,3}$.

Herein we report a case of Frantz's tumor in a 25-year-old woman without comorbidities which becomes cured after surgical resection of the tumor.

\section{CASE REPORT}

A 25-year-old female patient was admitted with history of intermittent abdominal pain, fever $\left(\mathrm{T}: 38^{\circ} \mathrm{C}\right)$ and diarrhea, also weight loss. Laboratory tests showed low white blood cell (WBC) count $\left(2,6 \times 10^{3}\right)$. Red blood cell level, platelets, Ana-screen, albumin, total bilirrubin and fractions, urine test, insulin, gastrin and chromogranin A were normal. Serologies to HIV, Hepatitis B and C were performed and both negative. Contrast abdominal CT showed enlarged pancreas with a hypodense lesion of nodular appearance and peripheral calcifications, measuring 3.3 $\mathrm{x} 3 \mathrm{~cm}$, in the tail, with contrast product uptake (Figure 1). The tumor markers carcinoembryonic antigen (CEA: 1,69 $\mathrm{mg} / \mathrm{ml}$ ), and carbohydrate antigen (CA19-9: 14,04 $\mathrm{U} / \mathrm{ml}$ )were all within the normal range. It was decided to perform subtotal pancreatectomy with lymphadenectomy, and opted for splenectomy and intraoperative liver biopsy. Figure 2 shows the macroscopic appearance of the tumor. The pathology of surgical resection of the pancreatic tumor showed solid pseudopapillary tumor compatible with Frantz's tumor, without lymph node and hepatic involvement (Figure 3). Immunohistochemistry confirmed histopathological findings (Table 1). The patient evolved postoperatively with pancreatic fistula and pancreatitis resolved after 15 days. Currently, it is being followed up in our service with complete remission of symptoms.

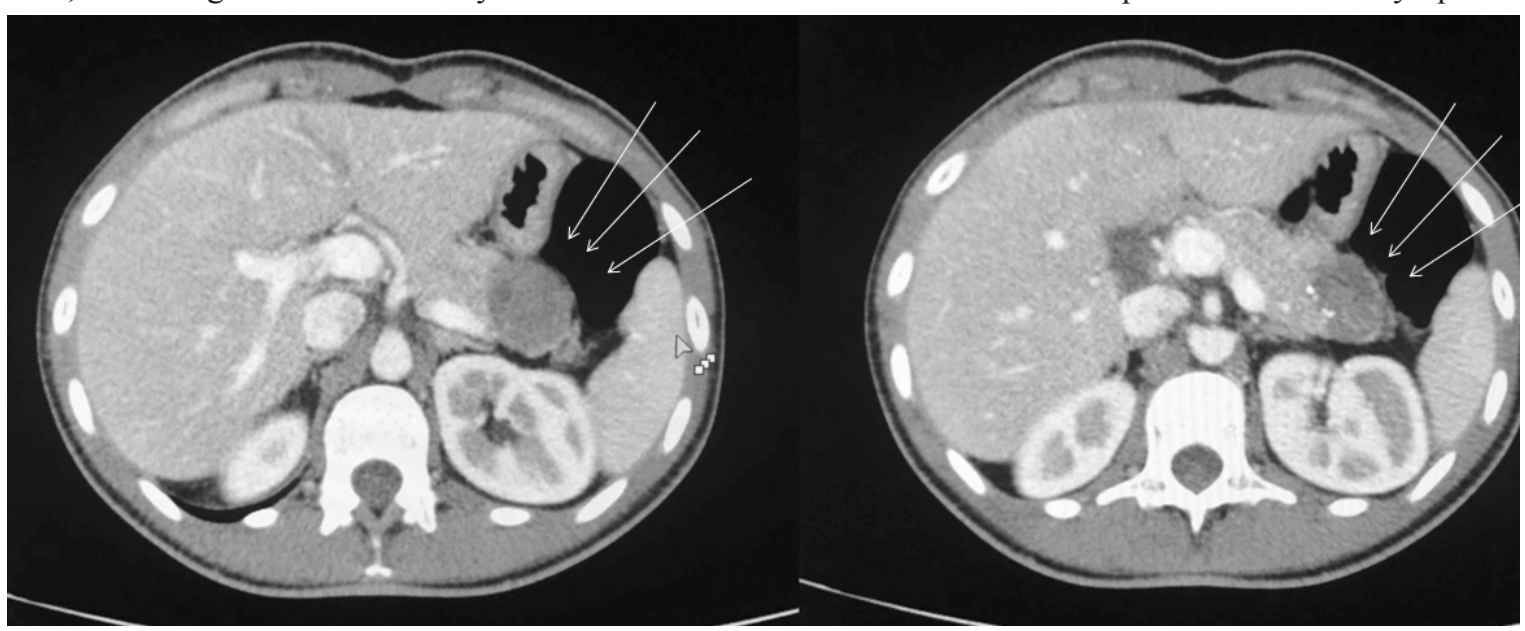

Figure 1. Computedtomography (CT) image of solid pseudopapillary tumor located in the tail of the pancreas

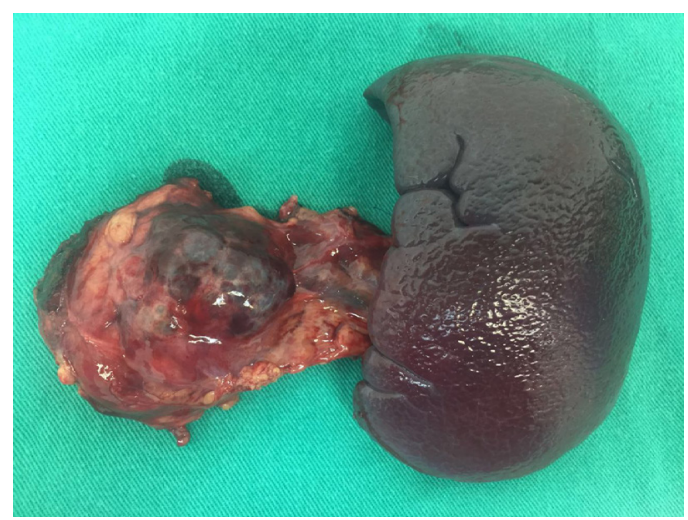

Figure 2. Pancreatic tumor between body and tail of the pancreas

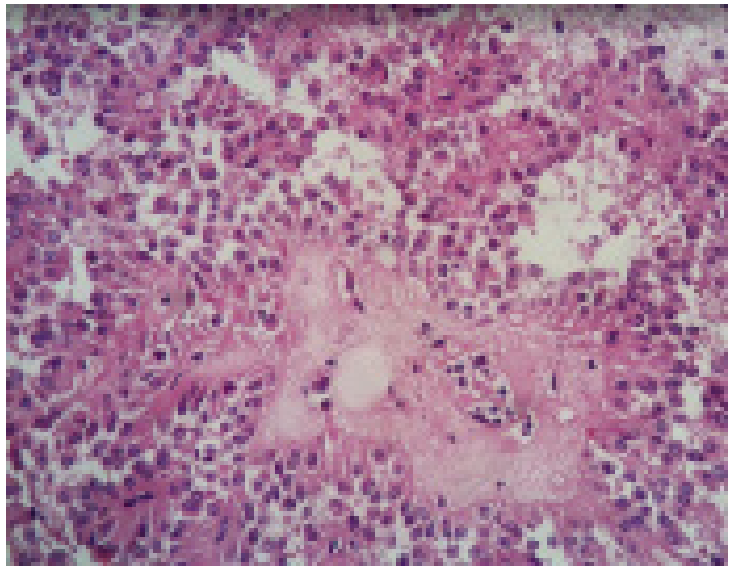

Figure 3. Proliferation of papillae with hyalinized fibrovascular axis coated by layers of epithelial cells that exhibit clear to eosinophil cytoplasm. Presence of intracytoplasmic PAS + cells. The pseudopapilas resemble rosettes in cross-sections. Pseudocystic areas are noted with hemorrhage 
Table 1. Immunohistochemical panel compatible with pseudopapillary tumor of the pancreas

\begin{tabular}{l|l|l}
\hline Antibody & Clone & Result \\
\hline$\beta$-Catenina & $\beta$-Catenina & Positive \\
\hline CD-10 & 56C6 & Positive \\
\hline CD-56 & $123 \mathrm{C} 3$ & Positive \\
\hline Citoceratina & AE1/AE3 & Positive \\
\hline CK 7 & OV-TL 12/30 & Negative \\
\hline CK 19 & RCK108 & Negative \\
\hline CK 20 & Ks20.8 & Negative \\
\hline Cromogranina A & Policlonal & Negative \\
\hline Ki-67 & MIB-1 & Positive \\
\hline Sinaptofisina & SY38 & Positive \\
\hline Vimentina & V9 & Positive \\
\hline
\end{tabular}

\section{DISCUSSION}

Commonly, the Frantz's tumor has a good prognosis as reported in the case. However, despite the low malignant potential, metastases are possible and are factors of worse prognosis. ${ }^{4}$ Metastasis occurs in approximately $15 \%$ of cases, usually restricted to the liver or peritoneum. Lymph node metastasis is also rare ${ }^{5}$.

Most tumors are clinically non-specific. The clinical features may be of abdominal pain or discomfort, mild abdominal pain or development of abdominal mass ${ }^{6}$. The presence of diarrhea in the patient besides abdominal pain raised doubts about the diagnosis, since diarrhea is a symptom present more commonly in tumors of neuroendocrine origin. The dosage of insulin, cromogranin A and gastrin helped in the diagnosis, as well as the accomplishment of the immunohistochemical panel. Unusual symptoms also described are vomiting, hematemesis, lack of appetite and weight loss ${ }^{7}$.

Although rare, reported cases in the world has increased $^{3,8}$. In the national literature, it is possible to find relevant case series with 4 to 14 patients $^{9,10}$. The disease predominantly affects young women ${ }^{1-3,6}$. Nevertheless, there are reported cases of the disease in children, male patients and old-aged ${ }^{11,12}$.

Differential diagnoses include a variety of pancreatic tumours including non-functioning islet tumour, mucinous cystic neoplasm, serous cystadenomas, acinar cell cancer, lymphoma, pancreatoblastoma and pseudocyst. The only way to confirm diagnosis is biopsy or excision as perfomed in the case. The endoscopic ultrasound-guided fine needle aspiration (EUS-FNA) may enable the preoperative and auxiliary diagnosis in the surgical approach to be used. However, the rate of false negatives in EUS-FNA is high and the procedure is not indicated when there is suspicion of localized malignancy in the pancreas body or tail, which is amenable to surgery. The common anatomopathological findings are: a mixture of papillary and solid or cystic patterns; the tumor cells may have an eosinophilic cytoplasm; they are uniform in size and are arranged around a central fibrovascular stalk ${ }^{1,2,3,5,13}$.

Traditionally, immunohistochemistry presents neuroendocrine markers, particularly chromogranin, which has been considered the marker in the differentiation between neuroendocrine tumor and Frantz's tumor. Positive CD10 is characteristic of pseudopapillary tumors and is less useful in the differential diagnosis, since it is positive in approximately $10 \%$ of invasive ductal adenocarcinomas and neuroendocrine tumors. Other markers suggestive of pseudopapillary solid tumor of the pancreas are vimentin, beta-catenin and progesterone. Alpha-1-antitrypsin and alpha-1-antiquimiotrypsin support pancreatic exocrine origin, while neurospecific enolase and synaptophysin are characteristic of neuroendocrine tumor ${ }^{14,15}$.

In presented case, abdominal $\mathrm{CT}$ was sufficient to evaluate the tumor resectability. However, if the abdominal CT is doubtful, it is possible to use other imaging methods, such as $\mathrm{MRI}^{6,9,10}$. The recommended treatment, due to the low degree of tumor malignancy and excellent prognosis, it is surgical, with complete resection of the tumor and high possibility of cure. Radiotherapy and chemotherapy are reserved for cases in which surgery is not feasible $e^{6,9,16}$. In these case the patient was young, had excellent general health, had no history of previous surgery, had no invasion of mesenteric vein, portal vein, or surrounding tissues, and had no lymph nodes metastases justifying the choice of surgical method.

\section{CONCLUSION}

The case discussed is relevant because the patient presented with diarrhea as a confounding fact, in detriment of other typical clinical-radiological findings that pointed to the diagnosis of Frantz's tumor, which was confirmed by the histopathological and immunohistochemical analysis. Regarding the prognosis, the presence well-formed capsule with absence of metastases and complete resection of the mass were important for favorable developments.

Consent: Written informed consent was obtained from the patient for publication of this case report and any accompanying images. 


\section{REFERENCES}

1. Frantz VK. Tumor of the pancreas. In: Frantz VK, editor. Atlas of tumor pathology. Washington, DC: Armed Forces Institute of Pathology. 1959. p.32-3.

2. Papavramidis T, Papavramidis S. Solid pseudopapillary tumors of the pancreas: review of 718 patients reported in the English literature. J Am Coll Surg. 2005;2:965-72. doi: 10.1016/j.jamcollsurg.2005.02.011.

3. Cai H, Zhou M, Hu Y, He H, Chen J, Tian W, et al. Solidpseudopapillary neoplasms of the pancreas: clinical and pathological features of 33 cases. Surg Today. 2013;43:14854. doi: 10.1007/s00595-012-0260-3.

4. Vollmer C, Dixon E. and Grant D. Management of a solid pseudopapillary tumor of the pancreas with liver metastases. HPB. 2003;5(4):264-7. doi: 10.1080/13651820310001397.

5. Matsunou H, Konishi F. Papillary-cysticneoplasm of the pancreas. A clinicopathologic study concerning the tumor aging and malignancy of nine cases. Cancer. 1990;65:285-91.

6. Reddy S, Cameron JL, Scudiere J, Hruban RH, Fishman EK, Ahuja N, Pawlik TM, Edil BH, Schulick RD, Wolfgang CL. Surgical management of solid-pseudopapillary neoplasms of the pancreas: a large single-institutional series. J Amer Coll Surg. 2009;208:950-9. doi: 10.1016/j.jamcollsurg.2009.01.044.

7. Apostolidis S, Papavramidis TS, Zatagias A, Michalopoulos A, Papadopoulos VN, Paramythiotis D, Harlaftis N. Hematemesis, a very rare presentation of solid-pseudopapillary tumors of the pancreas: a case report. J Med Case Rep. 2008;2:271. doi: 10.1186/1752-1947-2-271.

8. Branco C, Vilaça S. and Falcão J. Solid pseudopapillary neoplasm - case report of a rare pancreatic tumor. Int J Surg Case Rep. 2017;33:148-50. doi: 10.1016/j.ijscr.2017.02.049.

9. Cunha JEM, Machado MCC, Penteado S, Jukemura J, Abdo
EE, Bacchella T, Montagnini AL. Tratamento dos tumores císticos do pâncreas. In: Atualização em Cirurgia do Aparelho Digestivo e Coloproctologia. São Paulo: Frôntis Editorial; 2002. p.187-95.

10. Costa-Neto GD, Amico EC, Costa GID. Tumor sólido-cístico pseudopapilar do pâncreas (tumor de Frantz): estudo de quatro casos. Arq. Gastroenterol. 2004;41(4):259-62. doi: 10.1590/ S0004-28032004000400011.

11. Escobar, M., Bond, B. andSchopp, J. Solid pseudopapillary tumour (Frantz's tumour) of the pancreas in childhood. Case Rep. 2014;1-5. doi: 10.1136/bcr-2013-200889.

12. Klöppel G, Maurer R, Hofmann E, Lüthold K, Oscarson J, Forsby N, Ihse I, Ljungberg O, Heitz PU. Solid-cystic (papillary-cystic) tumors within and outside the pancreas in men: report of two patients. Virchows Arch A Pathol Anat Histopathol. 1991;418:179-83. doi: 10.1007/BF01600295.

13. Lam KY, Lo CY, Fan ST. Pancreatic solid-cystic-papillary tumor: clinicopathologic features in eight patients from Hong Kong and review of the literature. World J Surg. 1999;23:1045-50.

14. Nguyen NQ, Johns AL, Gill AJ, Ring N, Chang DK, Clarkson A, et al. Clinical and immunohistochemical features of 34 solid pseudopapillary tumors of the pancreas. J Gastroenterol Hepatol. 2011;26(2):267-74. doi: 10.1111/j.14401746.2010.06466.x.

15. Serra S, Chetty R. Revision 2: an immunohistochemical approach and evaluation of solid pseudopapillary tumour of the pancreas. J Clin Pathol. 2008;61(11):1153-9. doi: 10.1136/ jcp.2008.057828.

16. Berretta S, Barbagallo E, D'agata A, Berretta M. Frantz's solid cystic papillary pancreatic carcinoma. Minerva Chir 2001;56(4):413-9. 